\title{
Long-term carbon and nitrogen dynamics at SPRUCE revealed through stable isotopes in peat profiles
}

\author{
Erik A. Hobbie ${ }^{1}$, Janet Chen ${ }^{1,2}$, Paul J. Hanson ${ }^{3}$, Colleen M. Iversen ${ }^{3}$, Karis J. McFarlane ${ }^{4}$, Nathan R. Thorp ${ }^{1}$, and \\ Kirsten S. Hofmockel ${ }^{5,6}$ \\ ${ }^{1}$ Earth Systems Research Center, University of New Hampshire, Durham, New Hampshire, 03824, USA \\ ${ }^{2}$ Soil and Water Management \& Crop Nutrition Laboratory, FAO/IAEA Agriculture \& Biotechnology \\ Laboratories, Seibersdorf, Austria \\ ${ }^{3}$ Climate Change Science Institute and Environmental Sciences Division, Oak Ridge National Laboratory, \\ Oak Ridge, Tennessee, 37831, USA \\ ${ }^{4}$ Center for Accelerator Mass Spectrometry, Lawrence Livermore National Laboratory, \\ Livermore, California, 94551, USA \\ ${ }^{5}$ Department of Ecology, Evolution and Organismal Biology, Iowa State University, Ames, Iowa, 50011, USA \\ ${ }^{6}$ Pacific Northwest National Laboratory, Richland, Washington, 99354, USA
}

Correspondence to: Erik A. Hobbie (erik.hobbie@unh.edu)

Received: 21 July 2016 - Discussion started: 6 September 2016

Revised: 15 February 2017 - Accepted: 28 March 2017 - Published: 17 May 2017

\begin{abstract}
Peatlands encode information about past vegetation dynamics, climate, and microbial processes. Here, we used $\delta^{15} \mathrm{~N}$ and $\delta^{13} \mathrm{C}$ patterns from 16 peat profiles to deduce how the biogeochemistry of the Marcell S1 forested bog in northern Minnesota responded to environmental and vegetation change over the past $\sim 10000$ years. In multiple regression analyses, $\delta^{15} \mathrm{~N}$ and $\delta^{13} \mathrm{C}$ correlated strongly with depth, plot location, $\mathrm{C} / \mathrm{N}, \% \mathrm{~N}$, and each other. Correlations with $\% \mathrm{~N}, \% \mathrm{C}, \mathrm{C} / \mathrm{N}$, and the other isotope accounted for $80 \%$ of variance for $\delta^{15} \mathrm{~N}$ and $38 \%$ of variance for $\delta^{13} \mathrm{C}$, reflecting $\mathrm{N}$ and $\mathrm{C}$ losses. In contrast, correlations with depth and topography (hummock or hollow) reflected peatland successional history and climate. Higher $\delta^{15} \mathrm{~N}$ in plots closer to uplands may reflect upland-derived DON inputs and accompanying shifts in $\mathrm{N}$ dynamics in the lagg drainage area surrounding the bog. The Suess effect (declining $\delta^{13} \mathrm{CO}_{2}$ since the Industrial Revolution) lowered $\delta^{13} \mathrm{C}$ in recent surficial samples. High $\delta^{15} \mathrm{~N}$ from -35 to $-55 \mathrm{~cm}$ probably indicated the depth of ectomycorrhizal activity after tree colonization of the peatland over the last 400 years, as confirmed by the occasional presence of wood down to $-35 \mathrm{~cm}$ depth. High $\delta^{13} \mathrm{C}$ at $\sim 4000$ years BP $(-65$ to $-105 \mathrm{~cm})$ could reflect a transition at that time to slower rates of peat accumulation, when ${ }^{13} \mathrm{C}$ discrimination during peat decomposi-
\end{abstract}

tion may increase in importance. Low $\delta^{13} \mathrm{C}$ and high $\delta^{15} \mathrm{~N}$ at -213 and $-225 \mathrm{~cm}(\sim 8500$ years $\mathrm{BP})$ corresponded to a warm period during a sedge-dominated rich fen stage. The above processes appear to be the primary drivers of the observed isotopic patterns, whereas there was no clear evidence for methane dynamics influencing $\delta^{13} \mathrm{C}$ patterns.

\section{Introduction}

Carbon (C) and nitrogen (N) cycling are tightly linked (Schlesinger et al., 2011) and understanding the controls of $\mathrm{C}$ and $\mathrm{N}$ turnover in boreal peatlands is fundamental to predicting whether this ecosystem will continue to function as a strong $\mathrm{C}$ sink or switch to a source of carbon dioxide $\left(\mathrm{CO}_{2}\right)$ and methane $\left(\mathrm{CH}_{4}\right)$ in response to environmental change. While 80-90\% of C deposited in peatlands is lost via decomposition and microbial respiration in the upper aerobic layers of the acrotelm (Belyea and Malmer, 2004), the deeper anaerobic catotelm accumulates recalcitrant Sphagnum litter and other organic matter due to low mineral nutrient availability and waterlogged conditions. Carbon loss from the catotelm can be $50 \%$ within the first 1700 years with only an addi- 
tional $15 \%$ over the next 5800 years (Loisel et al., 2014), thus making peatlands an important long-term $\mathrm{C}$ sink.

Factors influencing $\mathrm{C}$ and $\mathrm{N}$ dynamics can be investigated using stable isotope measurements because biochemical and physical reactions proceed faster with lighter isotopes $\left({ }^{12} \mathrm{C}\right.$ and $\left.{ }^{14} \mathrm{~N}\right)$ than with heavier isotopes $\left({ }^{13} \mathrm{C}\right.$ and $\left.{ }^{15} \mathrm{~N}\right)$. Thus, different pools and fluxes can vary in their isotopic signatures (expressed as $\delta^{13} \mathrm{C}$ and $\delta^{15} \mathrm{~N}$ ). Climate and foliar $\% \mathrm{~N}$ can also influence the $\delta^{13} \mathrm{C}$ of plant photosynthate by determining the relative rates of stomatal flux versus fixation of $\mathrm{CO}_{2}$ (Brooks et al., 1998; Ménot and Burns, 2001; Sparks and Ehleringer, 1997). Radiocarbon measurements $\left({ }^{14} \mathrm{C}\right)$ are also important in biogeochemical research, as they allow dating of peat profiles and linking stable isotope patterns to specific climatic periods or vegetational phases of peatland succession. The dominant factors influencing organic $\mathrm{C}$ and $\mathrm{N}$ turnover can be identified by characterizing isotopic signatures of specific compounds or plant components through the peat profile (Nichols et al., 2009; Gavazov et al., 2016), but interpreting bulk peat signatures remains challenging. Deeper peats in the catotelm reflect both historic vegetation and accumulated effects of anaerobic fermentation occurring over thousands of years. In contrast, aerobic decomposition in the acrotelm alters biogeochemistry over shorter timescales.

Analysis of $\mathrm{C}$ and $\mathrm{N}$ in peatland cores is a potential way to determine key biogeochemical processes involved in organic matter burial and release. Cores taken through the peat profile trace the trajectory of peatland succession and contain the biogeochemical fingerprint of shifts in climate and vegetation states. For example, fens and bogs differ in the chemical and isotopic composition of the organic peat profile, reflecting differences in their $\mathrm{pH}$, redox state, hydrologic inputs, and relative abundance of vascular plants compared to Sphagnum (Vitt and Weider, 2006). Warming, drying, and increased $\mathrm{N}$ availability can also alter isotopic composition through changes in plant community composition, with concomitant effects on $\mathrm{C}$ and $\mathrm{N}$ dynamics, including enhanced production of greenhouse gases such as $\mathrm{CO}_{2}, \mathrm{CH}_{4}$, and nitrous oxide $\left(\mathrm{N}_{2} \mathrm{O}\right)$ (Yavitt et al., 1987; Regina et al., 1996; Bergman et al., 1999; Juutinen et al., 2010).

Our conceptual model of $\mathrm{C}$ and $\mathrm{N}$ dynamics during peatland succession is shown in Fig. 1. Methanogenesis, methanotrophy, refixation of methane-derived $\mathrm{CO}_{2}$, and plant composition influence the $\delta^{13} \mathrm{C}$ of surficial layers (Ficken et al., 1998; Pancost et al., 2000), and the resulting $\delta^{13} \mathrm{C}$ signal is subsequently altered further during diagenesis of these buried peat soils over time. Topography could also influence $\delta^{13} \mathrm{C}$ because oxygen availability decreases with increasing water depth, resulting in different levels of methanogenesis and methanotrophy in hummocks versus hollows. Topography further influences $\delta^{13} \mathrm{C}$ because hummock $\mathrm{C}$ is older than hollow $\mathrm{C}$ for equivalent depths below the mean bog surface. The anthropogenic addition of ${ }^{13} \mathrm{C}$-depleted $\mathrm{CO}_{2}$ to the atmosphere via the burning of fossil fuels (the
Suess effect; Ehleringer et al., 2000) also increases the gradient between ${ }^{13} \mathrm{C}$-depleted surficial horizons and older, ${ }^{13} \mathrm{C}$ enriched deeper horizons.

How $\mathrm{N}$ dynamics will influence $\delta^{15} \mathrm{~N}$ patterns is also shown in Fig. 1. In aerobic soils, uptake by mycorrhizal fungi and subsequent transfer of ${ }^{15} \mathrm{~N}$-depleted $\mathrm{N}$ to host plants increases the ${ }^{15} \mathrm{~N}$ divergence between deeper, ${ }^{15} \mathrm{~N}$-enriched horizons and surficial horizons (Hobbie and Ouimette, 2009), with such processes presumably not operating in Sphagnum and deep-rooted nonmycorrhizal plants (Kohzu et al., 2003), but potentially operating in forested bogs. Nitrogen transport from uplands can be considerable in the lagg drainage region surrounding a peatland (Verry and Janssens, 2011), and depending on the drainage $\delta^{15} \mathrm{~N}$, may influence the $\delta^{15} \mathrm{~N}$ of the receiving peatland. For example, lagg drainage could contribute ${ }^{15} \mathrm{~N}$-depleted nitrate or ${ }^{15} \mathrm{~N}$-enriched dissolved organic N (DON) (Kalbitz and Geyer, 2002) that differ isotopically from $\mathrm{N}$ fixation $(0 \%)$ or atmospheric $\mathrm{N}$ inputs (Stewart et al., 1995; Högberg, 1997). In addition, biogeochemical hotspots are important for $\mathrm{N}$ dynamics in peatlands (Hill et al., 2016). Microbial processing of organic matter in soils commonly increases the $\delta^{15} \mathrm{~N}$ and $\delta^{13} \mathrm{C}$ of the residual material (Nadelhoffer and Fry, 1994), although a N loss mechanism must also be present for $\delta^{15} \mathrm{~N}$ to be affected. Such processing decreases the $\mathrm{C} / \mathrm{N}$ of organic matter, since respiratory $\mathrm{C}$ losses are generally greater than $\mathrm{N}$ losses.

Here, we used $\delta^{15} \mathrm{~N}, \delta^{13} \mathrm{C}, \% \mathrm{~N}$, and $\% \mathrm{C}$ patterns of peat profiles, plant tissues, and fungal hyphae sampled from the Spruce and Peatland Responses Under Climatic and Environmental Change (SPRUCE) experimental site in northern Minnesota, USA, at the Marcell S1 bog to investigate potential factors influencing $\mathrm{C}$ and $\mathrm{N}$ turnover in peatlands. In addition to the continuous variables of elemental concentration, isotopic signatures, and depth, nominal variables included plot location, topography (hummock versus hollow), and vegetation (near trees or not). We used concurrent radiocarbon measurements (Iversen et al., 2014) to link the stable isotope measurements to the 11000 -year history of $\mathrm{C}$ and $\mathrm{N}$ dynamics at the SPRUCE experimental site. With this combination of data, we studied how in situ biogeochemistry and peatland succession may have influenced the isotopic profiles. We inferred the path of peatland succession from a prior study of the nearby S2 bog, as given in Table 1. Successional history at $\mathrm{S} 1$ should be similar, with the vegetation proceeding from a rich fen to a transitional fen $\sim 5500$ years BP, transitioning to a poor fen $\sim 2900$ years BP, and then changing to a forested bog $\sim 400$ years BP.

Isotopic patterns reflect numerous biogeochemical processes. Here, we addressed four potential drivers of isotopic variation in a boreal peatland profile:

1. microbial processing and biochemical composition (as inferred from $\% \mathrm{~N}, \% \mathrm{C}$, and $\mathrm{C} / \mathrm{N}$ ) will influence peatland $\delta^{13} \mathrm{C}$ and $\delta^{15} \mathrm{~N}$; 


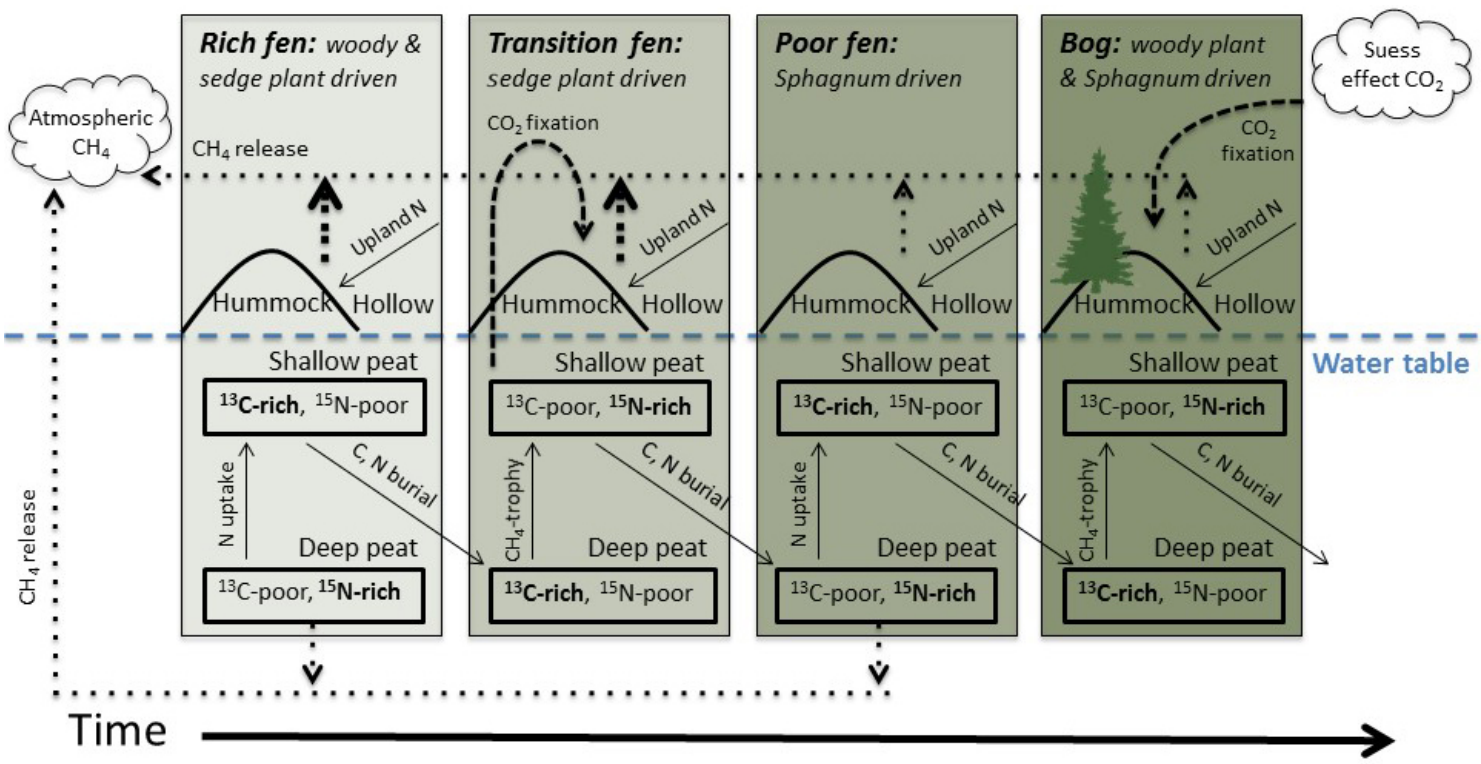

Figure 1. Conceptual diagram of movement of carbon (C) and nitrogen (N) during peatland development from rich fen to bog. Major processes influencing isotopic composition include methane $\left(\mathrm{CH}_{4}\right)$ flux from surficial and deeper layers (dotted upward arrow), methanotrophy and subsequent $\mathrm{CO}_{2}$ recapture by Sphagnum, vascular plant transport of methane, $\mathrm{N}$ uptake by vascular plants and mycorrhizal fungi, and the sequestration of $\mathrm{C}$ and $\mathrm{N}$ over time in deeper peat. Assimilation of ${ }^{13} \mathrm{C}$-depleted $\mathrm{CO}_{2}$ from the Suess effect influences modern peat carbon (rightmost top box); $\mathrm{N}$ flux from adjacent uplands influences productivity in the lagg region, peatland topography of hummocks and hollows influences methanogenesis and methanotrophy, and trees influence partitioning of nitrogen. Climate (not shown) will influence the initial $\delta^{13} \mathrm{C}$ of fixed carbon. By rotating the figure $90^{\circ}$ counterclockwise, the lower boxes correspond stratigraphically to the peat profile.

Table 1. Peatland stages at SPRUCE based on stratigraphy at the S2 watershed in the Marcell National Forest, USA (Verry and Janssens, 2011). MAT: mean annual temperature; MAP: mean annual precipitation.

\begin{tabular}{lll}
\hline Stage & Years BP & Climate \\
\hline & $9300-7400$ & MAT 4-5 $\left({ }^{\circ} \mathrm{C}\right)$, MAP 700 mm \\
& $9200-6500$ & Warm and dry \\
\hline Rich fen-sedge peat & $8400-5500$ & \\
& $7400-6100$ & $4{ }^{\circ} \mathrm{C} \rightarrow 2^{\circ} \mathrm{C}$, MAP 700-800 mm \\
& $6500-6000$ & $\begin{array}{l}\text { Cooling trend } \\
\text { Stable climate }\end{array}$ \\
& $6100-3200$ & \\
\hline Transitional fen & $5600-3000$ & \\
& $3200-2400$ & Cooled slightly \\
\hline Open poor fen & $2900-390$ & \\
& $2000-1800$ & Warmer and drier \\
\hline Little Ice Age & $600-150$ & Cooled $1^{\circ} \mathrm{C}$, MAT $800 \mathrm{~mm}$ \\
\hline Forested bog & $384 / 130-$ now & \\
\hline
\end{tabular}

2. proximity to uplands will increase $\mathrm{N}$ concentrations and peat $\delta^{15} \mathrm{~N}$;

3. peatland colonization by ectomycorrhizal trees will increase peat $\delta^{15} \mathrm{~N}$ and the ${ }^{15} \mathrm{~N}$ enrichment between surficial and deeper peat.
4. in upper peat layers, ${ }^{13} \mathrm{C}$ depletion will reflect anthropogenic declines in the $\delta^{13} \mathrm{C}$ of atmospheric $\mathrm{CO}_{2}$ (Suess effect).

In addition to these drivers, we will examine the covariation of peat $\delta^{13} \mathrm{C}$ and $\delta^{15} \mathrm{~N}$ with climate or vegetation through the Holocene. 


\section{Methods}

\subsection{Site description}

Soil and fungal samples were collected from the SPRUCE experimental site at the 8 ha S1 bog in the USDA Forest Service Marcell Experimental Forest in northern Minnesota, USA $\left(47^{\circ} 30.476^{\prime} \mathrm{N}, 93^{\circ} 27.162^{\prime} \mathrm{W}\right)$. The bog is dominated by the trees Picea mariana (Mill.) Britton, Sterns and Poggenb. and Larix laricina (Du Roi) K. Koch; ericaceous shrubs (Ledum groenlandicum Oeder; Chamaedaphne calyculata (L.) Moench.); and Sphagnum mosses. Various forbs and sedges are also present. The bog topography can be separated into hummocks (protruding above the average water table) and depressed hollows, and divided into areas with trees (Picea or Larix) or without trees. Average annual air temperature from 1961 to 2005 was $3.3^{\circ} \mathrm{C}$ with yearly mean extremes of -38 and $30^{\circ} \mathrm{C}$ and average annual precipitation of $768 \mathrm{~mm}$ (Sebestyen et al., 2011). Average $\mathrm{pH}$ of the peat is 4.1 and average gravimetric water content is $7.40 \mathrm{~g} \mathrm{H}_{2} \mathrm{O} \mathrm{g}^{-1}$ dry peat (Iversen et al., 2014). The water table fluctuates about $30 \mathrm{~cm}$ annually and water table depth can reach $1.4 \mathrm{~m}$ over the course of a 50-year record (Sebestyen et al., 2011). The bog maintains a perched water table with a hydraulic gradient about $1 \mathrm{~m}$ above the surrounding aquifer, which is composed of outwash sand (Verry et al., 2011). Because of the high water table, root distribution is quite shallow compared to upland sites (Iversen et al., 2017). In total, $93 \%$ of fine roots were in the $0-10 \mathrm{~cm}$ depth, $6 \%$ at $10-20 \mathrm{~cm}$ depth, and only $1 \%$ at $20-30 \mathrm{~cm}$ depth (A. Malhotra, personal communication, 2017). The boundary between the acrotelm and catotelm at SPRUCE is around $30-40 \mathrm{~cm}$ depth.

\subsection{Procedures}

Peat cores for this analysis were collected in mid-August of 2012 from locations along three boardwalks extending out into the bog beyond the lagg region (Fig. 2). Surface peat $(\sim 0-30 \mathrm{~cm})$ was collected using a modified hole saw, while deeper samples down to mineral soil $(\sim 30-250 \mathrm{~cm})$ were collected using a Russian peat corer. Cores were taken in both hummocks and hollows, with $0 \mathrm{~cm}$ defined as the surface of hollows and hummock heights above that assigned positive depths. Cores were bulked and homogenized every $10 \mathrm{~cm}$ over the 0 to $-100 \mathrm{~cm}$ depth, every $25 \mathrm{~cm}$ from -100 to $-200 \mathrm{~cm}$, and over the entire $50 \mathrm{~cm}$ increment from -200 to $-250 \mathrm{~cm}$ (in some cases, $-300 \mathrm{~cm}$ was reached before mineral soil was observed). Cores were sampled at 17 locations (Fig. 2; the locations of experimental plots distributed across the three boardwalks) and material from 16 of these locations was used for the $\delta^{13} \mathrm{C}, \delta^{15} \mathrm{~N}$, and radiocarbon measurements reported here. At locations 4, 5, 6, and 7 along the southern boardwalk, separate cores were taken within $150 \mathrm{~cm}$ of Picea or Larix trees and in the open (no trees within $150 \mathrm{~cm}$ ), and the distinction designated as "treed" or "untreed".

Peat cores were analyzed for $\Delta^{14} \mathrm{C}, \delta^{13} \mathrm{C}, \delta{ }^{15} \mathrm{~N}, \% \mathrm{C}, \% \mathrm{~N}$, and $\mathrm{C} / \mathrm{N}$ by depth increment, with the depth increment recorded as the average depth (for example, 0 to $10 \mathrm{~cm}$ in a hummock given as $5 \mathrm{~cm}$ ). Peat cores were analyzed in hummocks to a depth of $-10 \mathrm{~cm}$ and in hollows to the bottom of the core (between -200 and $-300 \mathrm{~cm}$ ). Live woody plant foliage and fine roots to $-10 \mathrm{~cm}$ were collected in August 2012 and live Sphagnum in 2013.

To collect fungal hyphae, in-growth cores were constructed. Mesh $(40 \mu \mathrm{m})$ in-growth bags $(10 \mathrm{~cm} \times 10 \mathrm{~cm})$ were filled with sterile sand. Bags were incubated in the field in paired hummock and hollows at six locations in the bog. In hummocks, bags were inserted at +10 to $0 \mathrm{~cm}$ above the adjacent hollow and in both locations from 0 to $-10 \mathrm{~cm}$ and -10 to $-20 \mathrm{~cm}$ below the hollow surface. Bags were installed on 5 June 2013 and recovered on 20 September 2013. Sand from in-growth bags was combined with ultrapure water and mixed at $80 \mathrm{rpm}$ for $20 \mathrm{~min}$. Suspended hyphae were removed with tweezers and the process was repeated until all hyphae were collected. Hyphal biomass was dried in the oven at $60^{\circ} \mathrm{C}$ for $48 \mathrm{~h}$. Of 30 in-growth samples, 20 generated enough hyphal mass for analysis. All 20 samples were treated as independent replicates in statistical analyses.

\subsection{Isotopic and elemental analysis}

Radiocarbon content of homogenized bulk peat was measured on the Van de Graaff FN accelerator mass spectrometer (AMS) at the Center for AMS at Lawrence Livermore National Laboratory. Peat samples were not chemically pretreated prior to ${ }^{14} \mathrm{C}$ measurement. Samples were prepared by sealed-tube combustion to $\mathrm{CO}_{2}$ in the presence of $\mathrm{CuO}$ and $\mathrm{Ag}$ and then reduced onto $\mathrm{Fe}$ powder in the presence of $\mathrm{H}_{2}$ (Vogel et al., 1984). Radiocarbon isotopic values had an average AMS precision of $2.6 \%$ and were corrected for mass-dependent fractionation with $\delta^{13} \mathrm{C}$ values from analyses conducted at the Department of Geological Sciences Stable Isotope Laboratory at the University of California, Davis, using a GVI Optima stable isotope ratio mass spectrometer. Radiocarbon values are reported here in $\Delta^{14} \mathrm{C}$ notation corrected for ${ }^{14} \mathrm{C}$ decay since 1950 (Stuiver and Polach, 1977). Calibrated ages were determined using Calib (http: //calib.qub.ac.uk/calib/) or CaliBomb (Reimer et al., 2004) with INTCAL13 (Reimer et al., 2013) and Northern Hemisphere Zone 1 bomb curve extension (Hua et al., 2013) atmospheric ${ }^{14} \mathrm{C}$ calibration curves. Years before present (BP) refer to years prior to 1950 . For more recent samples, calendar years AD may also be used.

These same soil samples and additional samples of hyphae and foliage were analyzed for $\% \mathrm{C}, \% \mathrm{~N}, \delta^{13} \mathrm{C}$, and $\delta^{15} \mathrm{~N}$ at the University of New Hampshire Stable Isotope Laboratory using a Costech 4010 elemental analyzer coupled to a Thermo Delta Plus XP IRMS. Standard deviations of labora- 


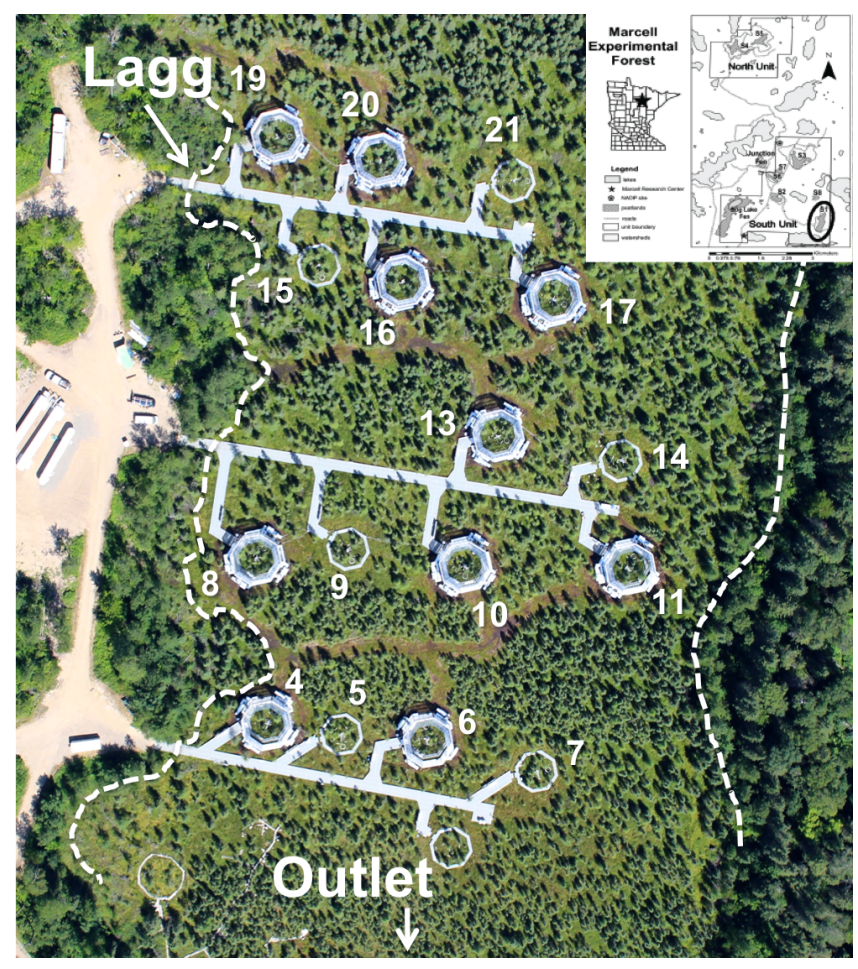

Figure 2. Aerial photograph of the $\mathrm{S} 1$ bog showing the 16 experimental plots (each $10.4 \mathrm{~m}$ in diameter to the outer edge of the visible perimeter boardwalk). Plot numbers on the image represent the plot areas within which peat was sampled. The lagg boundary is delineated with a dashed line, and the inset indicates the location of the bog within Minnesota and the Marcell Experimental Forest.

tory standards (tuna, NIST 1515 , and NIST $1575 \mathrm{a}$ ) for $\delta^{15} \mathrm{~N}$ and $\delta^{13} \mathrm{C}$ averaged less than $0.2 \%$. Fine roots of the woody vascular plants were analyzed for their stable isotopic composition at the Oak Ridge National Laboratory on an Integra CN mass spectrometer (SerCon, Crewe, UK), using standards traceable to NIST 8547-ammonium sulfate or 8542sucrose (NIST, Gaithersburg, Maryland, USA).

\subsection{Statistical tests}

The statistical program JMP (SAS Institute, Middleton, Massachusetts, USA) was used for statistical analyses. Reported values are $\pm \mathrm{SE}$, unless otherwise specified. Regression models for soil $\delta^{13} \mathrm{C}$ and $\delta^{15} \mathrm{~N}$ were tested. Factors included in the regression model included nominal variables of vegetation type (treed or non-treed), topography (hollow or hummock), and plot number. Depths with only a single measurement were generally excluded, unless they were very similar in depth to another value. Continuous variables included $\% \mathrm{~N}$, $\% \mathrm{C}$, and isotopic values.

To test whether plot location, proximity to trees, depth, topography, and elemental concentrations influenced the carbon and $\mathrm{N}$ isotope patterns in peat profiles, we used multiple regression analyses. Sample \%C, \% N , C N , and either $\delta^{13} \mathrm{C}$ or $\delta^{15} \mathrm{~N}$ were included as continuous variables. Because the effects of depth or plot location on $\mathrm{N}$ and $\mathrm{C}$ dynamics are unlikely to change continuously (for example, methanogenesis requires an anaerobic soil and plots at bog edges may have different hydrology and $\mathrm{N}$ dynamics than plots in the middle of the bog; Urban and Eisenreich, 1988), plot was treated as a nominal (categorical) variable in our regression models. To avoid over-parameterizing the model, depth was treated as a continuous variable with a cubic transformation (that is, the regression model included model depth, the square of model depth, and the cube of model depth as additional parameters). Stepwise regression was used and model selection based on the lowest Akaike information criterion with a correction for sample size (AICc). Within a given depth, values for radiocarbon were tested for correlations against $\delta^{13} \mathrm{C}$ and $\delta^{15} \mathrm{~N}$ and the slope of the regression estimated.

\section{Results}

\section{1 $\quad \delta^{13} \mathrm{C}$ and $\delta^{15} \mathrm{~N}$ in plants and fungal hyphae}

Of the six vascular plant taxa tested, $\delta^{13} \mathrm{C}$ of foliage varied from $-30 \%$ in Larix to $-28 \%$ in Picea. The $\delta^{15} \mathrm{~N}$ of plant foliage varied more widely than $\delta^{13} \mathrm{C}$, from $-8.5 \%$ for Picea to $2.5 \%$ or for Eriophorum. Fine root $\delta^{13} \mathrm{C}$ averaged $-27.4 \pm 0.3 \%$ for Larix, $-26.9 \pm 0.1 \%$ or Picea, and $-28.5 \pm 0.2 \%$ for shrubs. Fine root $\delta^{15} \mathrm{~N}$ averaged $-4.7 \pm 0.4 \%$ for Larix, $-4.1 \pm 0.3 \%$ of for Picea, and $-1.8 \pm 0.1 \%$ o for shrubs, whereas coarse roots of shrubs averaged $-3.4 \pm 0.3 \%$. If we assume plant productivity patterns are similar aboveground and belowground, then the productivity-weighted average in vascular plants for $\delta^{13} \mathrm{C}$ was $-29.2 \%$ of foliage and $-27.3 \%$ o for roots (Table 2 ). Fungal hyphae from in-growth cores $(n=20)$ averaged $-26.0 \pm 0.2 \%$ (se) for $\delta^{13} \mathrm{C}$ and $-0.3 \pm 0.2 \%$ for $\delta^{15} \mathrm{~N}$.

\section{$3.2 \delta^{13} \mathrm{C}$ and $\delta^{15} \mathrm{~N}$ in peat profiles}

Carbon isotope $\left(\delta^{13} \mathrm{C}\right)$ values of peat in the profile increased from $-29 \%$ in the top $10 \mathrm{~cm}$ of hummocks and hollows to $-26 \%$ at $-112 \mathrm{~cm}$ and then decreased slightly at greater depths. $\delta^{13} \mathrm{C}$ values changed most rapidly from $0 \mathrm{~cm}$ to $-50 \mathrm{~cm}$ depth (Fig. 3a). Nitrogen isotope values in the peat profile increased from $-3 \%$ in hummocks above the water level to around $1 \%$ at $-50 \mathrm{~cm} . \delta^{15} \mathrm{~N}$ then decreased to $0 \%$ at $-85 \mathrm{~cm}$ before increasing again to $1.5 \%$ at $-200 \mathrm{~cm}$. Similar to $\delta^{13} \mathrm{C}, \delta^{15} \mathrm{~N}$ changed most rapidly from $0 \mathrm{~cm}$ to $-50 \mathrm{~cm}$ depth (Fig. 3b).

In a stepwise regression model for $\delta^{13} \mathrm{C}$ including $\delta^{15} \mathrm{~N}$, $\mathrm{C} / \mathrm{N}, \% \mathrm{~N}, \% \mathrm{C}$, and depth as continuous variables and the vegetation type, topography, and plot sampling location as nominal variables, all factors were retained in our final model, including four terms for partitioning the 16 plots. The model explained $85 \%$ of the total variance $(n=238$, adjusted $r^{2}$ ) in peat $\delta^{13} \mathrm{C}$. The three depth terms (depth, depth 

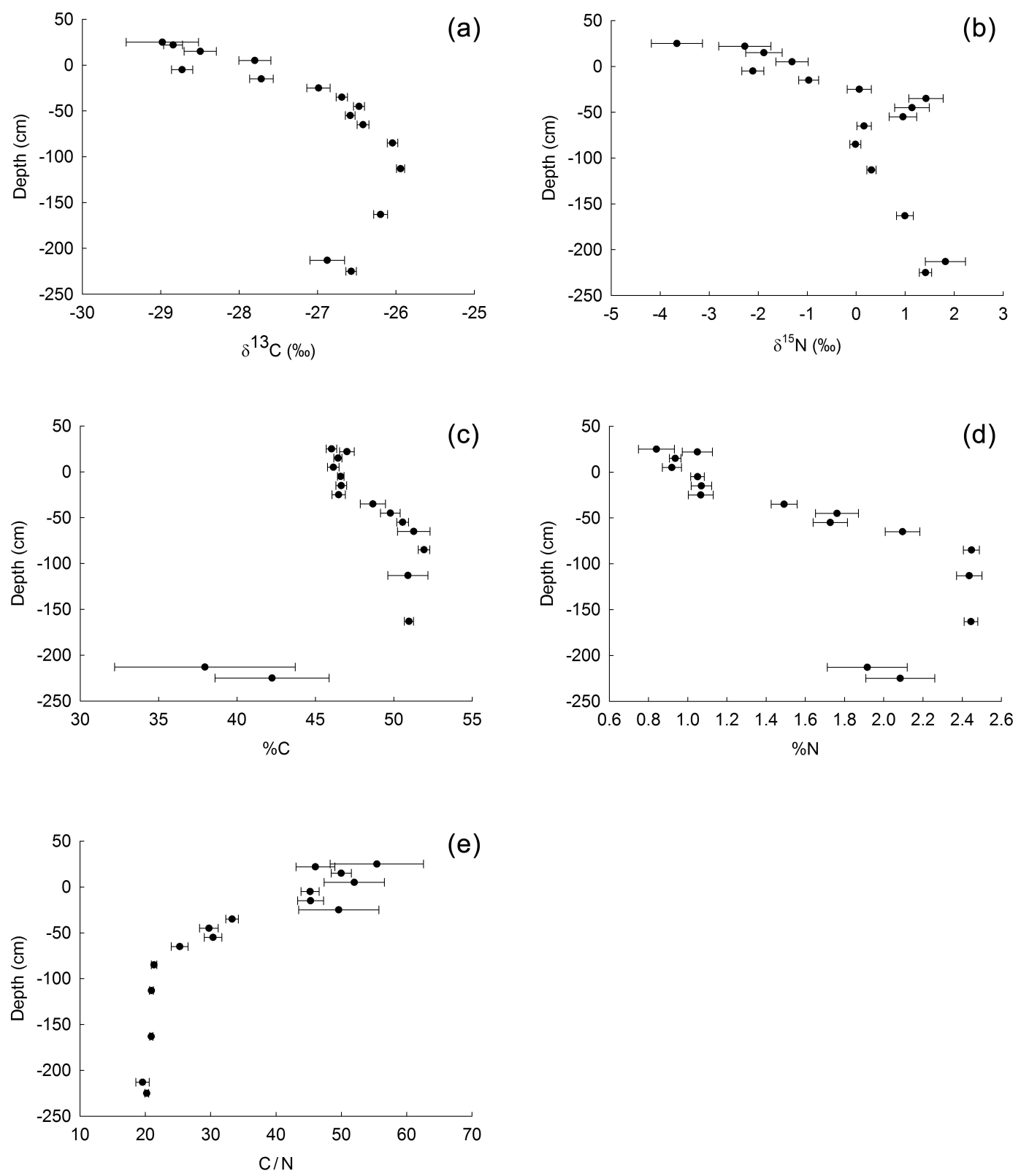

(e)

Figure 3. $\delta^{15} \mathrm{~N}, \delta^{13} \mathrm{C}, \% \mathrm{~N}, \% \mathrm{C}$, and $\mathrm{C} / \mathrm{N}$ versus depth. Values $( \pm \mathrm{SE})$ are averaged across hummock versus hollow cores and across treed versus non-treed cores. Averages $( \pm \mathrm{SE})$ are given for each depth, with $n$ given in parentheses following the depth: 25 (3), 22 (7), 15 (14), 5 (14), -5 (19), - 15 (17), -25 (17), -35 (15), -45 (17), -55 (17), -65 (17), -85 (18), -112 (17), -162 (17), -213 (3), and - 225 cm (8). (a) $\delta^{13} \mathrm{C}$ versus depth, (b) $\delta^{15} \mathrm{~N}$ versus depth, (c) $\% \mathrm{C}$ versus depth, (d) $\% \mathrm{~N}$ versus depth, and (e) $\mathrm{C} / \mathrm{N}$.

squared, and depth cubed) explained $45 \%, \% \mathrm{~N}$ explained $10 \%, \mathrm{C} / \mathrm{N} 11 \%, \delta^{15} \mathrm{~N} 15 \%, \% \mathrm{C}$ explained $2 \%$, the four plot terms explained $7 \%$, and proximity to trees explained $3 \%$ of the variance (Table 3 ). Topography explained $10 \%$ of variance, with hollows lower than hummocks by $0.89 \%$ in $\delta^{13} \mathrm{C}(p<0.001)$. Results of the stepwise model testing $\delta^{13} \mathrm{C}$ and $\delta^{15} \mathrm{~N}$ are given in Table S1.

The stepwise regression model for $\delta^{15} \mathrm{~N}$ of peat included $\delta^{13} \mathrm{C}$ and the same variables as in the $\delta^{13} \mathrm{C}$ regression model. This model explained $66 \%$ of the total variance (adjusted $r^{2}$ ), with proximity to trees and topography dropping out of the regression model. Of the explained variance, the three depth terms accounted for $8 \%, \% \mathrm{~N} 22 \%, \% \mathrm{C} 7 \%, \mathrm{C} / \mathrm{N}$ $17 \%, \delta^{13} \mathrm{C} 34 \%$, and the three plot terms $11 \%$ (Table 3 ).

The influence of depth and location in our regression models on $\delta^{13} \mathrm{C}$ and $\delta^{15} \mathrm{~N}$ values is plotted in Figs. 4 and 5, respectively. The influence of depth was negative above $0 \mathrm{~cm}$ (corresponding to the surface of the hollows), increased regularly from -5 to $-25 \mathrm{~cm}$, and then varied little in $\delta^{13} \mathrm{C}$ in the deepest horizons while still increasing in $\delta^{15} \mathrm{~N}$. There was 
Table 2. Average foliar values for $\delta^{13} \mathrm{C}, \delta^{15} \mathrm{~N}, \% \mathrm{C}, \% \mathrm{~N}$, and $\mathrm{C} / \mathrm{N}(n=7)$.

\begin{tabular}{|c|c|c|c|c|c|c|c|}
\hline Species & $\delta^{13} \mathrm{C} \pm \mathrm{SE}$ & $\delta^{15} \mathrm{~N} \pm \mathrm{SE}$ & $\% \mathrm{C} \pm \mathrm{SE}$ & $\% \mathrm{~N} \pm \mathrm{SE}$ & $\mathrm{C} / \mathrm{N} \pm \mathrm{SE}$ & $n$ & $\%$ C flux ${ }^{1}$ \\
\hline Chamaedaphne & $-29.5 \pm 0.1^{\mathrm{c}}$ & $-3.8 \pm 0.4^{\mathrm{c}}$ & $51.30 \pm 0.42^{\mathrm{a}}$ & $1.50 \pm 0.04^{b}$ & $34.53 \pm 0.88^{\mathrm{cd}}$ & 12 & 1.5 \\
\hline Eriophorum & $-28.4 \pm 0.2^{\mathrm{a}}$ & $2.5 \pm 0.6^{\mathrm{a}}$ & $45.16 \pm 0.21^{\mathrm{c}}$ & $1.45 \pm 0.06^{\mathrm{b}}$ & $31.49 \pm 1.36^{\mathrm{d}}$ & 9 & - \\
\hline Larix & $-30.4 \pm 0.1^{\mathrm{d}}$ & $-6.3 \pm 0.4^{\mathrm{d}}$ & $48.49 \pm 0.36^{\mathrm{bc}}$ & $0.77 \pm 0.06^{\mathrm{c}}$ & $65.10 \pm 5.17^{b}$ & 7 & 37 \\
\hline Ledum & $-29.2 \pm 0.1^{b c}$ & $-5.4 \pm 0.2^{\mathrm{d}}$ & $51.74 \pm 0.23^{\mathrm{a}}$ & $1.26 \pm 0.03^{b}$ & $41.21 \pm 1.07^{\mathrm{c}}$ & 13 & 6.6 \\
\hline Picea & $-28.0 \pm 0.2^{\mathrm{a}}$ & $-8.5 \pm 0.2^{\mathrm{e}}$ & $49.07 \pm 0.20^{b}$ & $0.63 \pm 0.02^{\mathrm{c}}$ & $79.44 \pm 3.24^{\mathrm{a}}$ & 11 & 38.3 \\
\hline Smilacina & $-28.7 \pm 0.2^{\mathrm{ab}}$ & $0.1 \pm 0.3^{b}$ & $47.20 \pm 0.53^{d}$ & $2.46 \pm 0.10^{\mathrm{a}}$ & $19.53 \pm 0.88^{\mathrm{e}}$ & 12 & 1.5 \\
\hline Sphagnum $^{2}$ & -29.2 & -2 & - & - & - & - & 15 \\
\hline Hollow ${ }^{3}$ & $-28.8 \pm 0.1$ & $-2.3 \pm 0.2$ & & & & & \\
\hline Hummock $^{3}$ & $-28.8 \pm 0.1$ & $-2.3 \pm 0.5$ & & & & & \\
\hline
\end{tabular}

${ }^{1}$ Weighted average of $\delta^{13} \mathrm{C}$ inputs is $-29.2 \%$, based on carbon fixation measurements of different taxa (R.J. Norby, personal communication). ANOVA comparing means in vascular plants used a post hoc Tukey test, with $\log \mathrm{C} / \mathrm{N}$ tested in place of C / N. ${ }^{2}$ Data from Tfaily et al. (2014). ${ }^{3}$ Top $10 \mathrm{~cm}$ only, primarily Sphagnum. Different superscripted letters after numbers within a column indicate a significant $(p<0.05)$ Tukey post hoc ANOVA test.

Table 3. Stepwise regression model for explaining $\delta^{13} \mathrm{C}$ and $\delta^{15} \mathrm{~N}$ in peat profiles at SPRUCE. Plot, topography (hummock versus hollow), and nearby presence of trees are treated as nominal variables. Value $=$ Coefficient \pm SE; Var $=\%$ variance explained; $n=238$. Depth in $\mathrm{cm}$, depth-squared and depth-cubed terms are also included in the model. Plots are sequentially separated into two groups to maximize the variance explained. Plot groups are Group $1,\{19 \& 8 \& 11 \& 20 \& 10 \& 15 \& 5$ vs. 9\& $16 \& 21 \& 6 \& 14 \& 4 \& 7 \& 13 \& 17\}$; Group 2 , $\{15$ vs. 5\}; Group $3,\{9 \& 16 \& 921 \& 6 \& 14 \& 4 \& 7$ vs. $13 \& 17\}$; Group $4,\{14 \& 4$ vs. 7$\}$; Group $5,\{10 \& 6 \& 11 \& 13 \& 9 \& 15$ vs. $17 \& 16 \& 5 \& 8 \& 14 \& 20 \& 7 \& 21 \& 19 \& 4\}$; Group 6, $\{13$ vs. 9\}; Group 7, $\{17 \& 16 \& 5 \& 8 \& 14 \& 20 \& 7 \& 21$ vs. $19 \& 4\}$. Within a group, the first plots listed have the given value, the second plots listed (after vs.) have the negative of the given value.

\begin{tabular}{lrrr|lrrr}
\hline \multicolumn{2}{c}{$\delta^{13} \mathrm{C}$ model, adjusted $r^{2}=0.846, p<0.001$} & \multicolumn{3}{c}{$\delta^{15} \mathrm{~N}$ model, adjusted $r^{2}=0.660, p<0.001$} \\
\hline Source & Value \pm SE & $\%$ Var & $P$ & Source & Value \pm SE & $\%$ Var & $P$ \\
Intercept & $-28.39 \pm 0.37$ & - & $<0.001$ & Intercept & $32.30 \pm 3.39$ & - & $<0.001$ \\
$\delta^{15} \mathrm{~N}$ & $0.196 \pm 0.025$ & 14.8 & $<0.001$ & $\delta^{13} \mathrm{C}$ & $1.164 \pm 0.115$ & 34 & $<0.001$ \\
$\% \mathrm{~N}$ & $1.036 \pm 0.162$ & 9.5 & $<0.001$ & $\% \mathrm{~N}$ & $-2.963 \pm 0.360$ & 22.5 & $<0.001$ \\
$\% \mathrm{C}$ & $-0.033 \pm 0.011$ & 2.3 & 0.002 & $\% \mathrm{C}$ & $0.107 \pm 0.023$ & 7 & $<0.001$ \\
$\mathrm{C} / \mathrm{N}$ & $0.025 \pm 0.004$ & 11 & $<0.001$ & $\mathrm{C} / \mathrm{N}$ & $-0.060 \pm 0.008$ & 17.1 & $<0.001$ \\
Hummock & $0.44 \pm 0.07$ & 9.6 & $<0.001$ & Hummock & - & - & - \\
Treed & $-0.12 \pm 0.05$ & 3.5 & 0.023 & Treed & & - & - \\
Depth & $-4.18 \pm 0.44 \mathrm{e}^{-2}$ & 21.2 & $<0.001$ & Depth & $-2.48 \pm 0.63 \mathrm{e}^{-2}$ & 5.1 & $<0.001$ \\
Depth & $-3.28 \pm 0.40 \mathrm{e}^{-4}$ & 15.4 & $<0.001$ & Depth & $-1.57 \pm 0.68 \mathrm{e}^{-4}$ & 1.8 & 0.021 \\
Depth & $-7.03 \pm 1.21 \mathrm{e}^{-7}$ & 7.9 & $<0.001$ & Depth & $-4.89 \pm 2.27 \mathrm{e}^{-7}$ & 1.6 & 0.032 \\
Group 1 & $-0.121 \pm 0.031$ & 3.5 & $<0.001$ & Group 5 & $-0.305 \pm 0.070$ & 6.3 & $<0.001$ \\
Group 2 & $0.151 \pm 0.081$ & 1.3 & 0.062 & Group 6 & $0.280 \pm 0.188$ & 0.7 & 0.137 \\
Group 3 & $-0.111 \pm 0.047$ & 1.5 & 0.018 & Group 7 & $-0.308 \pm 0.090$ & 3.9 & $<0.001$ \\
Group 4 & $-0.163 \pm 0.065$ & 1.2 & 0.013 & & & & \\
\hline
\end{tabular}

some spatial patterning of values across plots, with two plots (4 and 19) near to the western upland high in $\delta^{15} \mathrm{~N}$ (Figs. 2 and 5).

Although overall patterns of radiocarbon with depth were clear, radiocarbon varied widely at any given depth, and correlated significantly with $\delta^{13} \mathrm{C}$ or $\delta^{15} \mathrm{~N}$ at several depths (Table 4). Radiocarbon correlated positively with $\delta^{13} \mathrm{C}$ at -162 , $-5,5$, and $15 \mathrm{~cm}$, and correlated negatively with $\delta^{13} \mathrm{C}$ at -35 and $-65 \mathrm{~cm}$. In contrast, radiocarbon correlated positively with $\delta^{15} \mathrm{~N}$ at $-65,-55,-45,-5$, and $15 \mathrm{~cm}$, and correlated negatively with $\delta^{15} \mathrm{~N}$ at -162 and $-25 \mathrm{~cm}$. Overall patterns of $\Delta^{14} \mathrm{C}$ with $\delta^{13} \mathrm{C}$ or $\delta^{15} \mathrm{~N}$ are shown in Fig. 6a and b, respectively.

\section{Discussion}

\subsection{Potential causes of shifts in $\delta^{13} \mathrm{C}$ and $\delta^{15} \mathrm{~N}$ in peat profiles}

Isotopic ratios within the profile can shift if elemental fluxes in or out of the system differ isotopically from profile material (Fig. 1). Loss of labile $\mathrm{C}$ via respiration, methanogenesis, or leaching (Kolka et al., 1999) could alter the $\delta^{13} \mathrm{C}$ of the 
Table 4. Correlations between radiocarbon and stable isotopes by depth, and mean ${ }^{14} \mathrm{C}$ for that depth. Hummock vs. hollow plots and treed vs. non-treed plots were averaged together. $\delta^{13} \mathrm{C} \pm \mathrm{SE}$ and $\delta^{15} \mathrm{~N} \pm \mathrm{SE}$ columns reflect the shift in $\Delta^{14} \mathrm{C}$ with a $1 \%$ o shift in $\delta^{13} \mathrm{C}$ or $\delta^{15} \mathrm{~N}$. Statistically significant correlations are bolded.

\begin{tabular}{lrrlrrrrrr}
\hline Depth & & $\begin{array}{l}\text { Mean } \pm \text { SE } \\
\text { Age }\end{array}$ & $\begin{array}{l}\text { Age } \\
\text { (cal yr BP) }\end{array}$ & adj. $r^{2}$ & $\begin{array}{r}\delta^{13} \mathrm{C} \pm \mathrm{SE} \\
(\%)\end{array}$ & $P$ & adj. $r^{2}$ & $\begin{array}{r}\delta^{15} \mathrm{~N} \pm \mathrm{SE} \\
(\% \circ)\end{array}$ & $P$ \\
\hline 25 & 3 & $52 \pm 5$ & Modern & 0.881 & $10 \pm 3$ & 0.157 & -0.943 & $2 \pm 9$ & 0.892 \\
22 & 7 & $29 \pm 13$ & Modern & 0.325 & $69 \pm 35$ & 0.106 & -0.195 & $2 \pm 11$ & 0.889 \\
15 & 16 & $59 \pm 5$ & Modern & $\mathbf{0 . 2 1 9}$ & $\mathbf{1 3} \pm \mathbf{6}$ & $\mathbf{0 . 0 3 9}$ & $\mathbf{0 . 2 2 1}$ & $\mathbf{7} \pm \mathbf{3}$ & $\mathbf{0 . 0 3 8}$ \\
5 & 16 & $115 \pm 18$ & Modern & $\mathbf{0 . 6 8 2}$ & $\mathbf{7 4} \pm \mathbf{1 3}$ & $<\mathbf{0 . 0 0 1}$ & 0.039 & $17 \pm 14$ & 0.225 \\
-5 & 19 & $71 \pm 7$ & Modern & $\mathbf{0 . 3 5 2}$ & $\mathbf{3 3} \pm \mathbf{1 0}$ & $\mathbf{0 . 0 0 4}$ & $\mathbf{0 . 2 9 3}$ & $\mathbf{1 8} \pm \mathbf{6}$ & $\mathbf{0 . 0 1}$ \\
-15 & 19 & $126 \pm 19$ & Modern & -0.053 & $9 \pm 30$ & 0.762 & -0.024 & $-16 \pm 22$ & 0.459 \\
-25 & 20 & $100 \pm 23$ & Modern & 0.018 & $-41 \pm 35$ & 0.261 & $\mathbf{0 . 4 1 4}$ & $-\mathbf{6 2} \pm \mathbf{1 6}$ & $\mathbf{0 . 0 0 1}$ \\
-35 & 18 & $-102 \pm 34$ & $1580 \pm 180$ & $\mathbf{0 . 2 2 8}$ & $-\mathbf{2 4 6} \pm \mathbf{1 0 0}$ & $\mathbf{0 . 0 2 6}$ & -0.053 & $-9 \pm 24$ & 0.704 \\
-45 & 18 & $-182 \pm 27$ & $1730 \pm 260$ & -0.041 & $-54 \pm 95$ & 0.575 & $\mathbf{0 . 5 7 0}$ & $\mathbf{5 8} \pm \mathbf{1 2}$ & $<\mathbf{0 . 0 0 1}$ \\
-55 & 18 & $-203 \pm 19$ & nd & -0.025 & $-63 \pm 81$ & 0.447 & $\mathbf{0 . 5 1 2}$ & $\mathbf{5 2} \pm \mathbf{1 2}$ & $<\mathbf{0 . 0 0 1}$ \\
-65 & 18 & $-288 \pm 11$ & $2800 \pm 600$ & $\mathbf{0 . 4 8 6}$ & $-\mathbf{1 0 0} \pm \mathbf{2 4}$ & $<\mathbf{0 . 0 0 1}$ & $\mathbf{0 . 3 4}$ & $\mathbf{4 4} \pm \mathbf{1 4}$ & $\mathbf{0 . 0 0 6}$ \\
-85 & 18 & $-359 \pm 7$ & $3520 \pm 90$ & -0.007 & $-23 \pm 25$ & 0.362 & -0.049 & $-7 \pm 15$ & 0.651 \\
-113 & 18 & $-392 \pm 6$ & $3950 \pm 90$ & 0.081 & $42 \pm 27$ & 0.134 & 0.016 & $-17 \pm 15$ & 0.276 \\
-163 & 17 & $-486 \pm 7$ & $6000 \pm 500$ & $\mathbf{0 . 7 1 3}$ & $\mathbf{6 8} \pm \mathbf{1 1}$ & $<\mathbf{0 . 0 0 1}$ & $\mathbf{0 . 5 3 7}$ & $-\mathbf{3 1} \pm \mathbf{7}$ & $<\mathbf{0 . 0 0 1}$ \\
-213 & 3 & $-587 \pm 32$ & $9200 \pm 200$ & -0.811 & $-44 \pm 136$ & 0.801 & -0.96 & $-11 \pm 76$ & 0.912 \\
-225 & 11 & $-567 \pm 12$ & $6775 \pm 260$ & -0.089 & $27 \pm 62$ & 0.677 & -0.101 & $9 \pm 33$ & 0.784 \\
\hline
\end{tabular}

nd: not determined.

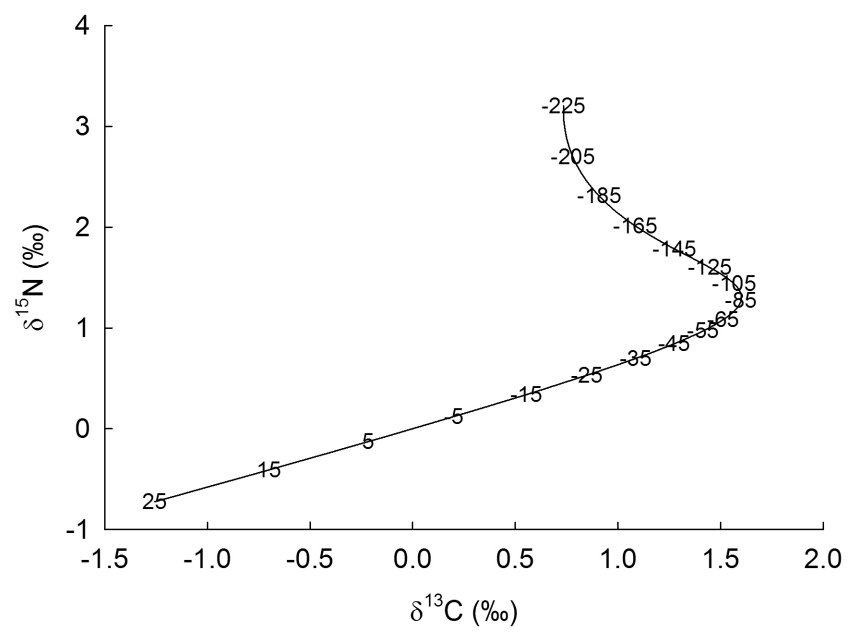

Figure 4. Depth coefficients of $\delta^{15} \mathrm{~N}$ and $\delta^{13} \mathrm{C}$ calculated from the three depth terms in the regression models. The depth in centimeters for specific points is indicated on the line.

residual material, as could inputs of ${ }^{13} \mathrm{C}$-enriched material such as roots or mycorrhizal hyphae. Similarly, changes in the $\delta^{13} \mathrm{C}$ of atmospheric $\mathrm{CO}_{2}$ can alter the $\delta^{13} \mathrm{C}$ of photosynthetically fixed $\mathrm{C}$, whereas changes in moisture, temperature, or photosynthetic capacity can alter the ${ }^{13} \mathrm{C}$ discrimination between atmospheric $\mathrm{CO}_{2}$ and fixed C. For N, loss of ${ }^{15} \mathrm{~N}$ depleted material from the bulk peat via mycorrhizal transfer to fine roots, direct root uptake, denitrification, or leaching of organic or inorganic $\mathrm{N}$ could raise the $\delta^{15} \mathrm{~N}$ of the remaining

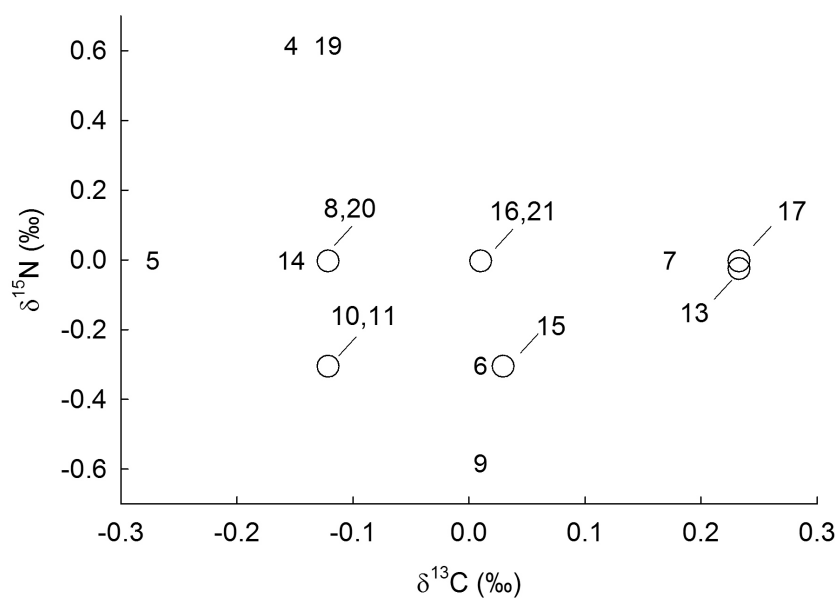

Figure 5. Plot coefficients of $\delta^{15} \mathrm{~N}$ and $\delta^{13} \mathrm{C}$ from regression models in peat profiles, as calculated from Table 1 . The plot number is the symbol for the paired coefficient values. For clarity, plots with identical or near-identical values are indicated with circles.

soil organic matter. Inputs of $\mathrm{N}$ via atmospheric deposition, $\mathrm{N}$ fixation, or transport from surrounding uplands could also influence $\delta^{15} \mathrm{~N}$ if these inputs differ isotopically from peat profile values. These processes can be linked to past climate and vegetation with profile radiocarbon measurements that are calibrated to calendar years. Here, we used radiocarbon to indicate the potential timing of shifts in some of the primary drivers that influenced $\mathrm{C}$ and $\mathrm{N}$ stable isotope patterns within the peat profiles at SPRUCE, such as the Suess effect 

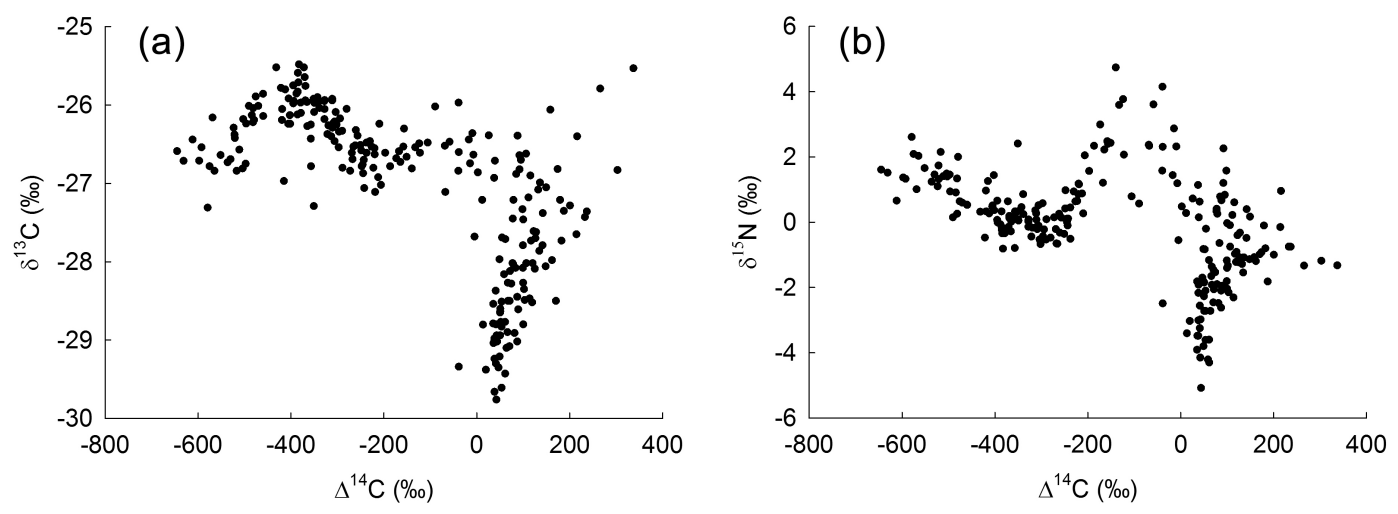

Figure 6. Relationship between $\Delta^{14} \mathrm{C}$ and (a) $\delta^{13} \mathrm{C}$; (b) $\delta^{15} \mathrm{~N}$.

and the transition to a forested bog, but also examined processes that were not tied to a particular time period, such as differences in $\mathrm{C}$ and $\mathrm{N}$ stoichiometry or proximity to uplands.

\section{2 \% $\mathrm{N}, \% \mathrm{C}$, and $\mathrm{C}: \mathrm{N}$ stoichiometry influenced $\delta^{13} \mathrm{C}$ and $\delta^{15} \mathrm{~N}$ patterns}

$\% \mathrm{~N}, \% \mathrm{C}$, and $\mathrm{C} / \mathrm{N}$ contributed a combined 47 and $23 \%$ of explained variance, respectively, to our regression models of $\delta^{15} \mathrm{~N}$ and $\delta^{13} \mathrm{C}$. These factors reflected the biochemical and isotopic composition of the original plant material, but also reflected how the chemical structure and isotopic composition of plant material has altered during its slow decomposition at S1.

Microbially driven $\mathrm{C}$ loss raises soil organic matter $\% \mathrm{~N}$, lowers $\mathrm{C} / \mathrm{N}$, and enriches soil organic matter in ${ }^{13} \mathrm{C}$ (resulting from loss of ${ }^{13} \mathrm{C}$-depleted $\mathrm{CO}_{2}$ ) (Ehleringer et al., 2000; Alewell et al., 2011). The positive correlation of $\% \mathrm{~N}$ with $\delta^{13} \mathrm{C}$ may therefore reflect an underlying correlation between the accumulation of ${ }^{13} \mathrm{C}$-enriched microbial necromass (Wallander et al., 2004) and the increased $\mathrm{N}$ content of the peatland organic matter. Fungal $\% \mathrm{~N}$ and $\delta^{13} \mathrm{C}$ are positively correlated (Hobbie et al., 2012) because of the high $\delta^{13} \mathrm{C}$ of microbially synthesized protein relative to other microbial components such as carbohydrates and lipids. In contrast, the positive correlation of $\mathrm{C} / \mathrm{N}$ with $\delta^{13} \mathrm{C}$ and negative correlation with $\delta^{15} \mathrm{~N}$ presumably reflect a legacy of buried wood, which, relative to other plant material, should be high in $\delta^{13} \mathrm{C}$ (Trudell et al., 2004) and high in $\mathrm{C} / \mathrm{N}$. This can be seen clearly in the few samples with $\mathrm{C} / \mathrm{N}$ greater than 70 , which is higher than any plant tissue measured in this study. Although some Sphagnum taxa under pristine conditions can be very low in $\% \mathrm{~N}(0.22 \%)$ and $\delta^{15} \mathrm{~N}(-3.6 \%)$ and high in C / N ( 190) (Asada et al., 2005a), here, the presence of wood was noted seven times during laboratory examination of the 238 samples at depths from 15 to $-35 \mathrm{~cm}$, with those samples twice as high in $\mathrm{C} / \mathrm{N}$ (average, 69) as other samples and also significantly higher in $\mathrm{C} / \mathrm{N}$ in multiple regression analysis (see Table S2).
The negative correlation of $\% \mathrm{~N}$ with $\delta^{15} \mathrm{~N}$ indicated that either added or removed $\mathrm{N}$ is low in $\delta^{15} \mathrm{~N}$. One possibility for removal is that ${ }^{15} \mathrm{~N}$-depleted $\mathrm{N}$ has been transferred from mycorrhizal fungi to plants. Alternatively, $\mathrm{N}$ could be added via fixation with a $\delta^{15} \mathrm{~N}$ value of $-1 \%$, which would lower overall $\delta^{15} \mathrm{~N}$ values deeper in the peat profile. However, we point out that only at -45 and $-55 \mathrm{~cm}$ are $\% \mathrm{~N}$ and $\delta^{15} \mathrm{~N}$ significantly and negatively correlated (Table S3). At these depths, $\% \mathrm{~N}$ is about $1.8 \%$ and $\delta^{15} \mathrm{~N}$ is about $1 \%$ (Fig. $3 \mathrm{~b}, \mathrm{~d}$ ). The value of the coefficient for $\% \mathrm{~N}$ in the $\delta^{15} \mathrm{~N}$ regression, $-2.96 \% \% \% \mathrm{~N}^{-1}$, implied that the perturbing $\mathrm{N}$ has a $\delta^{15} \mathrm{~N}$ value that is $1.8 \% \times 2.96 \% \circ \% \mathrm{~N}^{-1}$ less than that of $1 \%$, or $-4.3 \%$, which is too low to be fixed $\mathrm{N}$. The apparent ${ }^{15} \mathrm{~N}$ depletion of $5.3 \%$ against the source $\mathrm{N}$ is a plausible value for ${ }^{15} \mathrm{~N}$ discrimination between mycorrhizal fungi and host plants (Hobbie and Colpaert, 2003).

Correlations of carbon concentration with stable isotopes provide information about chemical composition or degree of processing. The negative correlation of $\% \mathrm{C}$ with $\delta^{13} \mathrm{C}$ is expected based on the chemical composition of ${ }^{13} \mathrm{C}$-depleted compound classes of lignin, aromatics, and lipids, which are high in \%C (Poorter et al., 1997; Hobbie et al., 2002). Initial decomposition of Sphagnum commonly decreases $\delta^{13} \mathrm{C}$, as ${ }^{13} \mathrm{C}$-enriched soluble components are leached (Asada et al., 2005b). In contrast, aromatics and lipids do not generally contain $\mathrm{N}$, so the positive correlation of $\% \mathrm{C}$ with $\delta^{15} \mathrm{~N}$ in bulk peat cannot be explained in the same manner. However, microbial processing generally enriches soils in ${ }^{15} \mathrm{~N}$ (Billings and Richter 2006; Templer et al., 2007) while increasing \%C, which was also true at S1 (Tfaily et al., 2014).

\subsection{Proximity to uplands and trees increased peat $\delta^{15} \mathrm{~N}$}

Plot-specific coefficients for $\delta^{13} \mathrm{C}$ and $\delta^{15} \mathrm{~N}$ may reflect sitespecific differences in the dominance of conditions favoring ${ }^{13} \mathrm{C}$ - or ${ }^{15} \mathrm{~N}$-depleted losses during peatland development. The positive coefficients for $\delta^{15} \mathrm{~N}$ are from two plots, 4 and 19 , closest to the lagg region adjacent to the western upland. This suggests that the different hydrology in the lagg 
has enhanced ${ }^{15} \mathrm{~N}$ fractionation from $\mathrm{N}$ removal mechanisms such as denitrification, nitrification, or leaching of DON. Alternatively, dissolved $\mathrm{N}$ transported from the uplands during spring thaw and melt may have provided an additional ${ }^{15} \mathrm{~N}$ enriched $\mathrm{N}$ source for plots 4 and 19 located near the bog edges (Fig. 5). Peatland DON appears enriched in ${ }^{15} \mathrm{~N}$ and ${ }^{13} \mathrm{C}$ relative to bulk peat (Broder et al., 2012), and this is presumably true for upland sources as well. In the adjacent Marcell S2 kettle bog, large $\mathrm{N}$ fluxes from upland locations from both surface runoff and interflow led to much larger $\mathrm{N}$ losses in streamflow from the lagg region $\left(\sim 32 \mathrm{~kg} \mathrm{ha}^{-1} \mathrm{yr}^{-1}\right)$ than from the bog itself $\left(2 \mathrm{~kg} \mathrm{ha}^{-1} \mathrm{yr}^{-1}\right)$ (Urban and Eisenreich, 1988). The uplands here are dominated by ectomycorrhizal trees such as Populus, Quercus, and Pinus, which produce vertically stratified soil profiles with high $\delta^{15} \mathrm{~N}$ values in lower organic and mineral horizons (Hobbie and Ouimette, 2009). We therefore expect DON produced in uplands to be high in $\delta^{15} \mathrm{~N}$, which will serve as a source of ${ }^{15} \mathrm{~N}$-enriched $\mathrm{N}$ to lagg regions of peatlands.

\section{4 $\delta^{15} \mathrm{~N}$ patterns with depth reflected climate and vegetation}

Peatland succession and climate have been established previously at the nearby S2 bog and are summarized in Table 1 . As the same climatological factors affected the S2 and S1 (SPRUCE) bogs, plant stratigraphy and isotopic patterns were probably similar, although accumulation rates are lower at S1 than at S2 (McFarlane, unpublished data).

In the following paragraphs, we link shifts in $\delta^{15} \mathrm{~N}$ through the profile to radiocarbon ages and the corresponding patterns in vegetation and climate at the $\mathrm{S} 2 \mathrm{bog}$. The high $\delta^{15} \mathrm{~N}$ at -213 and $-225 \mathrm{~cm}$ corresponded approximately to a warm period between 8000 and 9200 years BP, during a sedge-rich fen stage (Verry and Janssens, 2011), with mean annual temperatures of $4-5{ }^{\circ} \mathrm{C}$. Given similar $\mathrm{C} / \mathrm{N}$ ratios during this period to subsequent periods $(\sim 20)$, nitrogen losses were probably more depleted in ${ }^{15} \mathrm{~N}$ than subsequent losses, that is, more losses via nitrate leaching or denitrification rather than via DON leaching. Nitrification and denitrification are higher in fens than in bogs and should change $\delta^{15} \mathrm{~N}$ patterns along the core profile as the core reflects peatland succession and climatological changes (Regina et al., 1996; Bayley et al., 2005; Wray and Bayley, 2007).

The S2 bog shifted from a rich fen to a transitional fen by 5600 years BP, while mean annual temperature (MAT) decreased to perhaps $2{ }^{\circ} \mathrm{C}$. At the $\mathrm{S} 1 \mathrm{bog}$, the negative correlation between radiocarbon and $\delta^{15} \mathrm{~N}$ at $-162 \mathrm{~cm}$ ( $\sim 6000$ years BP) suggested decreasing losses of ${ }^{15} \mathrm{~N}$ depleted $\mathrm{N}$ during this transition. The depth increment from -85 to $-112 \mathrm{~cm}$ corresponded to a transitional fen stage 3300-4800 years BP. The accompanying trough in $\delta^{15} \mathrm{~N}$ at $-400 \%$ $\Delta^{14} \mathrm{C}$ (4220 calibrated years BP, Fig. 6b) suggested decreased sequestration of ${ }^{15} \mathrm{~N}$-enriched organic matter as nutrient availability declined during this transition.
The positive correlations between $\delta^{15} \mathrm{~N}$ and $\Delta^{14} \mathrm{C}$ at -45 , -55 , and $-65 \mathrm{~cm}$ (Table 4 and Fig. $6 \mathrm{~b}$ ) are linked to a parallel decline in $\% \mathrm{~N}$ over these time periods, so that younger samples are lower in $\% \mathrm{~N}$ and higher in $\delta^{15} \mathrm{~N}$ than older samples, reflecting losses of ${ }^{15} \mathrm{~N}$-depleted $\mathrm{N}$ from the younger samples. $\delta^{15} \mathrm{~N}$ values peaked at -35 to $-55 \mathrm{~cm}$, and then declined above and below those depths. This pattern suggested that those depths were affected by a ${ }^{15} \mathrm{~N}$ enrichment process that did not affect deeper depths (that is, further in the past). The peak $\delta^{15} \mathrm{~N}$ accordingly reflected ${ }^{15} \mathrm{~N}$ partitioning between surficial and deeper horizons by a new mechanism.

We suggest that ectomycorrhizal fungi are the most probable cause of this unusual peak in $\delta^{15} \mathrm{~N}$ at intermediate depths in the peat bog. At the nearby S2 bog, poor fen transitioned to forested bog between AD 1610 and 1864, with a charcoal layer at S2 indicating that peat was consumed by fire during this period, precluding a more specific date for this transition (Verry and Janssens, 2011). This forested bog is dominated by ectomycorrhizal Picea and Larix. Transfer to plants of ${ }^{15} \mathrm{~N}$-depleted $\mathrm{N}$ by ectomycorrhizal fungi leads to low plant $\delta^{15} \mathrm{~N}$ and high ${ }^{15} \mathrm{~N}$ enrichment of the residual $\mathrm{N}$ not transferred (Hobbie and Hobbie, 2008; Hobbie and Högberg, 2012). Here, the apparent influence of ectomycorrhizal uptake can be traced to $\sim-55 \mathrm{~cm}$.

The relatively low contribution of ectomycorrhizal and ericoid mycorrhizal fungi to total plant uptake here compared to forest sites dominated by ectomycorrhizal fungi accounted for the lower ${ }^{15} \mathrm{~N}$ enrichment between surficial layers and deeper layers here $(\sim 3 \%$ ) than in forest soils, which averaged a $9.6 \%$ enrichment between surficial and deeper soils for ectomycorrhizal forests (reviewed in Hobbie and Ouimette, 2009). Ectomycorrhizal and ericoid mycorrhizal trees and shrubs contributed relatively little to total $\mathrm{N}$ uptake at the nearby Marcell S2 bog, where mosses contributed $75 \%$ of total plant uptake, herbaceous plants $13 \%$, and mycorrhizal trees and shrubs $13 \%$ (Urban and Eisenreich, 1988). A few studies in peatlands have reported $\delta^{15} \mathrm{~N}$ values through profiles, but those values have peaked at -1 to $0 \%$ and have been in systems without ectomycorrhizal trees present (Krüger et al., 2015; Esmeijer-Liu et al., 2011).

\section{5 $\delta^{13} \mathrm{C}$ patterns with depth reflected climatic factors}

Once shifts in $\delta^{13} \mathrm{C}$ caused by compositional shifts are removed, the remaining patterns can be explained by invoking climatic or vegetation shifts. The relatively low $\delta^{13} \mathrm{C}$ at -213 and $-225 \mathrm{~cm}$ corresponded to a warm period between 8000 and 9200 years BP, during a sedge-dominated rich fen stage (Verry and Janssens, 2011), with mean annual temperatures of $4-5{ }^{\circ} \mathrm{C}$. Higher temperatures in peatlands are associated with lower $\delta^{13} \mathrm{C}$ values (Skrzypek et al., 2005, 2008).

Radiocarbon and $\delta^{13} \mathrm{C}$ correlated positively at $-162 \mathrm{~cm}$, corresponding to a $1 \%$ rise in $\delta^{13} \mathrm{C}$ which accompanied a drop in MAT to perhaps $2{ }^{\circ} \mathrm{C}$ by 6000 years BP. This cooling trend was also accompanied by a slight rise in precipitation, 
so the decreased ${ }^{13} \mathrm{C}$ discrimination could also be attributed to increased Sphagnum moisture (Rice and Giles, 1996), although it is difficult to distinguish between these two possible causes of ${ }^{13} \mathrm{C}$ differences (Ménot and Burns, 2001). Sphagnum discrimination is less with increased moisture because $\mathrm{CO}_{2}$ diffusion is limited under wet conditions. The stratigraphy at the $\mathrm{S} 2$ bog indicated a vegetational shift from a rich fen to a transitional fen during this period.

The depth increment from -85 to $-112 \mathrm{~cm}$ corresponded to a transitional fen stage 3300-4800 years ago. In our regression model for $\delta^{13} \mathrm{C}$ (Fig. 4), these two depths are about $0.5 \%$ higher in $\delta^{13} \mathrm{C}$ than at $-162 \mathrm{~cm}$. The peak in $\delta^{13} \mathrm{C}$ may reflect a phase during which sedges transported methane directly to the atmosphere, thereby minimizing the refixation in Sphagnum cells of ${ }^{13} \mathrm{C}$-depleted, methanotrophic-derived carbon dioxide (Raghoebarsing et al., 2005).

\subsection{The Suess effect increased ${ }^{13} \mathrm{C}$ depletion in surficial peat}

The strong dependence of $\delta^{13} \mathrm{C}$ on peat depth partially reflected the $1.7 \%$ o decline in the $\delta^{13} \mathrm{C}$ of atmospheric $\mathrm{CO}_{2}$ since 1850 , with the lowest $\delta^{13} \mathrm{C}$ values above the water table, where $\mathrm{C}$ is of recent origin. For example, the lowest estimated values of the $\delta^{13} \mathrm{C}$ depth coefficients $(\sim-1 \%$ ) in hummocks at 15,22 , and $25 \mathrm{~cm}$ above the mean hollow surface reflect $\mathrm{C}$ from the last 50 years (Fig. 4), as confirmed by $\Delta{ }^{14} \mathrm{C}$ averages of 59,29 , and $52 \%$ or these three depths, where only $\mathrm{C}$ influenced by ${ }^{14} \mathrm{C}$ created during thermonuclear testing should have positive $\Delta^{14} \mathrm{C}$ values (Table 4). Although our sampling lacked sufficient vertical resolution to explicitly include corrections for the Suess effect (e.g., as done in Esmeijer-Liu et al., 2012), the $\sim 2 \%$ o increase in the depth coefficient of our $\delta^{13} \mathrm{C}$ regression model from the hummocks to deeper in the profile correspond well to the long-term shift in $\delta^{13} \mathrm{C}$ of atmospheric $\mathrm{CO}_{2}$ from preindustrial times to the present. An additional factor contributing to the higher depth coefficient could be the 1-2\%o higher $\delta^{13} \mathrm{C}$ in roots than in foliage and the different input depths of foliage (surface only) and roots (distributed throughout the acrotelm). The steady increase in $\delta^{13} \mathrm{C}$ between -5 and $-25 \mathrm{~cm}$ depth (Fig. 4) presumably reflected the increasing dominance of preindustrial C. Depths of $-35 \mathrm{~cm}$ and below all had $\Delta{ }^{14} \mathrm{C}$ values less than $-100 \%$ (Table 4 ), indicating primarily pre-bomb and preindustrial $\mathrm{C}$ when the average $\delta^{13} \mathrm{C}$ of atmospheric $\mathrm{CO}_{2}$ was $-6.5 \%$ o (versus the current value of $-8.2 \%$ ). In addition, modern production of organic matter averaged $-29 \%$ in $\delta^{13} \mathrm{C}$ (Table 2), similar to values for surficial horizons, whereas deeper horizons were between -27 and $-26 \%$. The Suess effect of $\sim 1.5 \%$ o therefore accounted for at least half of this difference.

\section{Conclusions}

Although the multiple potential interactions among climate, vegetation, and soil processes made definitive conclusions difficult, we identified several factors that influenced $\delta^{13} \mathrm{C}$ and $\delta^{15} \mathrm{~N}$ patterns in peatland profiles, including the Suess effect, $\mathrm{C}$ and $\mathrm{N}$ stoichiometry, microbial processing, proximity to uplands, and tree colonization. The potential roles of methanogenesis versus respiration in influencing $\delta^{13} \mathrm{C}$ could not be addressed using bulk samples, since ${ }^{13} \mathrm{C}$ shifts were relatively small. Future measurements of deuterium isotope ratios $(\delta \mathrm{D})$ would allow separation of effects of respiration (loss of $\mathrm{CO}_{2}$ ) versus methane flux on $\delta^{13} \mathrm{C}$ patterns, since methanogenesis discriminates against deuterium. Our conceptual model as given in Fig. 1 included the Suess effect (influencing $\delta^{13} \mathrm{C}$ patterns) and $\mathrm{N}$ transport from uplands (probably influencing $\delta^{15} \mathrm{~N}$ patterns), but missed several additional factors that appeared to be important in controlling the isotopic patterns we reported. Buried wood appeared to influence both $\delta^{13} \mathrm{C}$ and $\delta^{15} \mathrm{~N}$ directly, and the ectomycorrhizal fungi associated with tree species here created a ${ }^{15} \mathrm{~N}$ enriched horizon that may be specific to forested peatlands. The model did not consider $\mathrm{N}$ loss mechanisms and associated ${ }^{15} \mathrm{~N}$ effects, nor did it consider the potential for ${ }^{13} \mathrm{C}$ differences between roots and aboveground litter to influence $\delta^{13} \mathrm{C}$ profiles. One potential way forward is to put these multiple processes into quantitative models of peatland development that includes vegetation succession and climatic drivers, such as the Holocene Peatland Model (Frolking et al., 2010), and to adapt these models to make isotopic predictions that can be compared against data. Such model-data comparisons should continue to improve our ability to interpret isotopic patterns, as well as reveal areas where our model formulations are currently inadequate.

Data availability. The data presented in this study are available in the appendices and through the Iversen et al. (2014) publication.

\section{The Supplement related to this article is available online at doi:10.5194/bg-14-2481-2017-supplement.}

Author contributions. Samples were collected by Colleen M. Iversen, Paul J. Hansen, and Kirsten S. Hofmockel and analyzed by Janet Chen, Erik A. Hobbie, Colleen M. Iversen, and Karis J. Mcfarlane. Erik A. Hobbie prepared the manuscript with contributions from all authors.

Competing interests. The authors declare that they have no conflict of interest. 
Acknowledgements. The authors appreciate field sampling efforts of members of the SPRUCE research group, in particular Jana Phillips, Deanne Brice, and Joanne Childs. This material is based upon work supported by grant ER65430 to Iowa State University from the US Department of Energy, and the SPRUCE experiment is supported by the US Department of Energy, Office of Science, Office of Biological and Environmental Research. This paper was authored by UT-Battelle, LLC under contract no. DE-AC05-00OR22725 with the US Department of Energy. The United States Government retains and the publisher, by accepting the article for publication, acknowledges that the United States Government retains a non-exclusive, paid-up, irrevocable, world-wide license to publish or reproduce the published form of this manuscript, or allow others to do so, for United States Government purposes. The Department of Energy will provide public access to these results of federally sponsored research in accordance with the DOE Public Access Plan (http://energy.gov/downloads/doe-public-access-plan). The data referenced in this paper are archived at and available from the SPRUCE long-term repository (Iversen et al., 2014; http://mnspruce.ornl.gov). The authors are grateful for comments on the manuscript by Tim Moore and several anonymous reviewers.

Edited by: P. Stoy

Reviewed by: T. Moore and three anonymous referees

\section{References}

Alewell, C., Giesler, R., Klaminder, J., Leifeld, J., and Rollog, M.: Stable carbon isotopes as indicators for environmental change in palsa peats, Biogeosciences, 8, 1769-1778, doi:10.5194/bg-81769-2011, 2011.

Asada, T., Warner, B. G., and Aravena, R.: Nitrogen isotope signature variability in plant species from open peatland, Aquat. Bot., 82, 297-307, 2005a.

Asada, T., Warner, B., and Aravena, R.: Effects of the early stage of decomposition on change in carbon and nitrogen isotopes in Sphagnum litter, J. Plant Interact., 1, 229-237, 2005 b.

Bayley, S. E., Thormann, M. N., and Szumigalski, A. R.: Nitrogen mineralization and decomposition in western boreal bog and fen peat, Ecoscience, 12, 455-465, 2005.

Belyea, L. R. and Malmer, N.: Carbon sequestration in peatland: patterns and mechanisms of response to climate change, Glob. Change Biol., 10, 1043-1052, 2004.

Bergman, I., Lundberg, P., and Nilsson, M.: Microbial carbon mineralisation in an acid surface peat: effects of environmental factors in laboratory incubations, Soil Biol. Biochem., 31, 18671877, 1999.

Billings, S. A. and Richter, D. D.: Changes in stable isotopic signatures of soil nitrogen and carbon during 40 years of forest development, Oecologia, 148, 325-333, 2006.

Broder, T., Blodau, C., Biester, H., and Knorr, K. H.: Peat decomposition records in three pristine ombrotrophic bogs in southern Patagonia, Biogeosciences, 9, 1479-1491, doi:10.5194/bg9-1479-2012, 2012.

Brooks, J. R., Flanagan, L. B., and Ehleringer, J. R.: Responses of boreal conifers to climate fluctuations: indications from tree-ring widths and carbon isotope analyses, Can. For. Res., 28, 524-533, 1998.

Ehleringer, J. R., Buchmann, N., and Flanagan, L. B.: Carbon isotope ratios in belowground carbon cycle processes, Ecol. Appl., 10, 412-422, 2000.

Esmeijer-Liu, A. J., Kürschner, W. M., Lotter, A. F., Verhoeven, J. T., and Goslar, T.: Stable carbon and nitrogen isotopes in a peat profile are influenced by early stage diagenesis and changes in atmospheric $\mathrm{CO}_{2}$ and $\mathrm{N}$ deposition, Water Air Soil Pollut., 223, 2007-2022, 2012.

Ficken, K. J., Barber, K. E., and Eglinton, G.: Lipid biomarker, $\delta^{13} \mathrm{C}$ and plant macrofossil stratigraphy of a Scottish montane peat bog over the last two millennia, Org. Geochem., 28, 217-237, 1998.

Frolking, S., Roulet, N. T., Tuittila, E., Bubier, J. L., Quillet, A., Talbot, J., and Richard, P. J. H.: A new model of Holocene peatland net primary production, decomposition, water balance, and peat accumulation, Earth Syst. Dynam., 1, 1-21, doi:10.5194/esd-11-2010, 2010.

Gavazov, K., Hagedorn, F., Buttler, A., Siegwolf R., and Bragazza L.: Environmental drivers of carbon and nitrogen isotopic signatures in peatland vascular plants along an altitude gradient, Oecologia, 180, 257-264, 2016.

Hill, B. H., Jicha, T. M., Lehto, L. L., Elonen C. M., Sebestyen, S. D., and Kolka, R. K..: Comparisons of soil nitrogen mass balances for an ombrotrophic bog and a minerotrophic fen in northern Minnesota, Sci. Total Environ., 550, 880-892, 2016.

Hobbie, E. A. and Colpaert, J. V.: Nitrogen availability and colonization by mycorrhizal fungi correlate with nitrogen isotope patterns in plants, New Phytol., 151, 115-126, 2003.

Hobbie, E. A. and Hobbie, J. E.: Natural abundance of ${ }^{15} \mathrm{~N}$ in nitrogen-limited forests and tundra can estimate nitrogen cycling through mycorrhizal fungi: A review, Ecosystems, 11, 815-830, 2008.

Hobbie, E. A. and Högberg, P.: Nitrogen isotopes link mycorrhizal fungi and plants to nitrogen dynamics, New Phytol., 196, 367382, 2012.

Hobbie, E. A. and Ouimette, A. P.: Controls of nitrogen isotope patterns in soil profiles, Biogeochemistry, 95, 355-371, 2009.

Hobbie, E. A., Tingey, D. T., Rygiewicz, P. T., Johnson, M. G., and Olszyk, D. M.: Contributions of current year photosynthate to fine roots estimated using a ${ }^{13} \mathrm{C}$-depleted $\mathrm{CO}_{2}$ source, Plant Soil, 247, 233-242, 2002.

Hobbie, E. A., Sánchez, F. S., and Rygiewicz, P. T.: Controls of isotopic patterns in saprotrophic and ectomycorrhizal fungi, Soil Biol. Biochem., 48, 60-68, 2012.

Hofmockel, K. S., Chen, J., and Hobbie, E. A.: SPRUCE S1 Bog Pretreatment Fungal Hyphae Carbon and Nitrogen Concentrations and Stable Isotope Composition from In-growth Cores, 2013-2014, Carbon Dioxide Information Analysis Center, Oak Ridge National Laboratory, Oak Ridge, Tennessee, USA, doi:10.3334/CDIAC/spruce.025, 2016.

Högberg, P.: ${ }^{15} \mathrm{~N}$ natural abundance in soil-plant systems, New Phytol., 137, 179-203, 1997.

Hua, Q., Barbetti, M., and Rakowski, A.: Atmospheric radiocarbon for the period 1950-2010, Radiocarbon, 55, 2059-2072, 2013.

Iversen, C. M., Hanson, P. J., Brice, D. J., Phillips, J. R., McFarlane, K. J., Hobbie, E. A., and Kolka, R. K.: SPRUCE peat physical and chemical characteristics from experimental plot cores, 2012, Carbon Dioxide Information Analysis Center, Oak Ridge 
National Laboratory, US Department of Energy, Oak Ridge, Tennessee, USA, doi:10.3334/CDIAC/spruce.005, 2014.

Iversen, C. M., Childs, J., Norby, R. J., Ontl, T. A., Kolka, R. K., Brice, D. J., McFarlane, K. J., and Hanson, P. J.: Fine-root growth in a forested bog is seasonally dynamic, but shallowly distributed in nutrient-poor peat, Plant Soil, 1-21, doi:10.1007/s11104-0173231-z, 2017.

Juutinen, S., Bubier, J. L., and Moore, T. R.: Responses of vegetation and ecosystem $\mathrm{CO}_{2}$ exchange to 9 years of nutrient addition at Mer Bleue bog, Ecosystems, 13, 874-887, 2010.

Kalbitz, K. and Geyer, S.: Different effects of peat degradation on dissolved organic carbon and nitrogen, Org. Geochem., 33, 319326, 2002.

Kohzu, A., Matsui, K., Yamada, T., Sugimoto, A., and Fujita, N.: Significance of rooting depth in mire plants: Evidence from natural ${ }^{15} \mathrm{~N}$ abundance, Ecol. Res., 18, 257-266, 2003.

Kolka, R. K., Grigal, D. F., Verry, E. S., and Nater, E. A.: Mercury and organic carbon relationships in streams draining forested upland/peatland watersheds, J. Environ. Qual., 28, 766-775, 1999.

Krüger, J. P., Leifeld, J., Glatzel, S., Szidat, S., and Alewell, C.: Biogeochemical indicators of peatland degradation - a case study of a temperate bog in northern Germany, Biogeosciences, 12, 28612871, doi:10.5194/bg-12-2861-2015, 2015.

Loisel, J., Yu, Z., Beilman, D. W., Camill, P., Alm, J., Amesbury, M. J., Anderson, D., Andersson, S., Bochicchio, C., and Barber, K.: A database and synthesis of northern peatland soil properties and Holocene carbon and nitrogen accumulation, The Holocene, 24, 1028-1042, 2014.

Ménot, G. and Burns, S. J.: Carbon isotopes in ombrogenic peat bog plants as climatic indicators: calibration from an altitudinal transect in Switzerland, Org. Geochem., 32, 233-245, 2001.

Nadelhoffer, K. and Fry, B.: N isotope studies in forests, Stable Isotopes in Ecology and Environmental Sciences, Oxford, Blackwell, 22-62, 1994.

Nichols, J. E., Walcott, M., Bradley, R., Pilcher, J., and Huang, Y.: Quantitative assessment of precipitation seasonality and summer surface wetness using ombrotrophic sediments from an Arctic Norwegian peatland, Quat. Res., 72, 443-45, 2009.

Pancost, R. D., van Geel, B., Baas, M., and Damste, J. S. S.: $\delta^{13} \mathrm{C}$ values and radiocarbon dates of microbial biomarkers as tracers for carbon recycling in peat deposits, Geology, 28, 663-666, 2000.

Poorter, H., Berkel, Y., Baxter, R., Hertog. J. D., Dijkstra, P., Gifford, R., Griffin, K., Roumet, C., Roy, J., and Wong, S.: The effect of elevated $\mathrm{CO}_{2}$ on the chemical composition and construction costs of leaves of $27 \mathrm{C}_{3}$ species, Plant Cell Environ., 20, 472-482, 1997.

Raghoebarsing, A. A., Smolders, A. J., Schmid, M. C., Rijpstra, W. I. C., Wolters-Arts, M., Derksen, J., Jetten, M. S., Schouten, S., Damsté, J. S. S., and Lamers, L. P.: Methanotrophic symbionts provide carbon for photosynthesis in peat bogs, Nature, 436, 1153-1156, 2005.

Regina, K., Nykänen, H., Silvola, J., and Martikainen, P. J.: Fluxes of nitrous oxide from boreal peatlands as affected by peatland type, water table level and nitrification capacity, Biogeochemistry, 35, 401-418, 1996.

Reimer, P. J., Brown T. A., and Reimer, R. W.: Discussion: Reporting and Calibration of Post-Bomb ${ }^{14} \mathrm{C}$ Data. Oak Ridge, Tennessee, USA, doi:10.3334/CDIAC/spruce.005, 2004.
Reimer, P. J., Bard, E., Bayliss, A., Beck, J. W., Blackwell, P. G., Bronk, R. C., Buck, C. E., Cheng, H., Edwards, R. L, Friedrich, M., Grootes, P. M., Guilderson, T. P., Haflidason, H., Hajdas, I., Hatté, C., Heaton, T. J., Hoffmann, D. L., Hogg, A. G., Hughen, K. A., Kaiser, K. F., Kromer, B., Manning, S. W., Niu, M., Reimer, R. W., Richards, D. A., Scott, E. M., Southon, J. R., Staff, R. A., Turney, C. S. M., and van der Plicht, J.: IntCal13 and Marine13 radiocarbon age calibration curves $0-50000$ years cal BP, Radiocarbon, 55, 1869-1887, 2013.

Rice, S. and Giles, L.: The influence of water content and leaf anatomy on carbon isotope discrimination and photosynthesis in Sphagnum, Plant Cell Environ., 19, 118-124, 1996.

Schlesinger, W. H., Cole, J. J., Finzi, A. C., and Holland, E. A.: Introduction to coupled biogeochemical cycles, Front. Ecol. Environ., 9, 5-8, 2011.

Sebestyen, S. D., Dorrance, C., Olson, D. M., Verry, E. S., Kolka, R. K., Elling, A. E., and Kyllander, R.: Long-term monitoring sites and trends at the Marcell Experimental Forest, in: Peatland biogeochemistry and watershed hydrology at the Marcell Experimental Forest, edited by: Kolka, R. K., Sebestyen, S. D., Verry, E. S., and Brooks, K. N., Boca Raton, FL, CRC Press, 15-71, 2011.

Skrzypek, G., Jędrysek, M., and Keller-Sikora A.: Calibration of temperature carbon isotopic effect (peat bogs Hala Izerska, Izerskie Mts. and Szrenica, Karkonosze Mts.), Pol. Geological Inst. Spec. Papers, 16, 123-126, 2005.

Skrzypek, G., Paul, D., and Wojtun, B.: Stable isotope composition of plants and peat from Arctic mire and geothermal area in Iceland, Pol. Polar Res., 29, 365-376, 2008.

Sparks, J. and Ehleringer, J. R.: Leaf carbon isotope discrimination and nitrogen content for riparian trees along elevational transects, Oecologia, 109, 362-367, 1997.

Stewart, G. R., Schmidt, S., Handley, L. L., Turnbull, M. H., Erskine, P. D., and Joly, C. A.: ${ }^{15} \mathrm{~N}$ natural abundance of vascular rainforest epiphytes: implications for nitrogen source and acquisition, Plant Cell Environ., 18, 85-90, 1995.

Stuiver, M. and Polach, H. A.: Discussion; reporting of C-14 data, Radiocarbon, 19, 355-363, 1977.

Templer, P. H., Arthur, M. A., Lovett, G. M., and Weathers, K. C.: Plant and soil natural abundance $\delta^{15} \mathrm{~N}$ : indicators of relative rates of nitrogen cycling in temperate forest ecosystems, Oecologia, 153, 399-406, 2007.

Tfaily, M. M., Cooper, W. T., Kostka, J., Chanton, P. R., Schadt, C. W., Hanson, P. J., Iversen, C. M., and Chanton, J. P.: Organic matter transformation in the peat column at Marcell Experimental Forest: humification and vertical stratification, J. Geophys. Res.Biogeosci., 119, 661-675, 2014.

Trudell, S. A, Rygiewicz, P. T., and Edmonds, R. L.: Patterns of nitrogen and carbon stable isotope ratios in macrofungi, plants and soils in two old-growth conifer forests, New Phytol., 164, 317-335, 2004.

Urban N. R. and Eisenreich, S. J.: Nitrogen cycling in a forested Minnesota bog, Can. J. Bot., 66, 435-449, doi:10.1139/b88-069, 1988.

Verry, E. S. and Janssens, J.: Geology, vegetation, and hydrology of the S2 bog at the MEF: 12,000 years in northern Minnesota, in: Peatland biogeochemistry and watershed hydrology at the Marcell Experimental Forest, edited by: Kolka, R. K., Sebestyen, S. 
D., Verry, E. S., and Brooks, K. N., Boca Raton, FL, CRC Press, 93-134, 2011.

Verry, E. S., Brooks, K. N., Nichols, D. S., Ferris, D. R., and Sebestyen, S. D.: Watershed hydrology, in: Peatland biogeochemistry and watershed hydrology at the Marcell Experimental Forest, edited by: Kolka, R. K., Sebestyen, S. D., Verry, E. S., and Brooks, K. N., Boca Raton, FL, CRC Press, 193-212, 2011.

Vitt, D. H. and Wieder, R. K..: Boreal peatland ecosystems: our carbon heritage, Boreal Peatland and Ecosystems, Springer, Berlin, 425-429, 2006.

Vogel, J. S., Southon, J. R., Nelson, D., and Brown, T. A.: Performance of catalytically condensed carbon for use in accelerator mass spectrometry, Nucl. Instr. Meth. Phys. Res. Sect. B, 5, 289293, 1984.
Wallander, H., Göransson, H., and Rosengren, U.: Production, standing biomass and natural abundance of ${ }^{15} \mathrm{~N}$ and ${ }^{13} \mathrm{C}$ in ectomycorrhizal mycelia collected at different soil depths in two forest types, Oecologia, 139, 89-97, 2004.

Wray, H. E. and Bayley, S. E.: Denitrification rates in marsh fringes and fens in two boreal peatlands in Alberta, Canada, Wetlands, 27, 1036-1045, 2007.

Yavitt, J. B., Lang, G. E., and Wieder, R. K.: Control of carbon mineralization to $\mathrm{CH}_{4}$ and $\mathrm{CO}_{2}$ in anaerobic, Sphagnum-derived peat from Big Run Bog, West Virginia, Biogeochemistry, 4, 141 157, 1987. 